\title{
Implementasi Peraturan Daerah Nomor 1 Tahun 2019 Tentang Retribusi Jasa Umum Dalam Pengelolaan Retribusi Pasar Di Pasar Raya Padang
}

\author{
Fresha Atmuria ${ }^{1}$ dan Afriva Khaidir ${ }^{2}$ \\ 1Jurusan Ilmu Administrasi Publik, Universitas Negeri Padang \\ 2Jurusan Ilmu Administrasi Publik, Universitas Negeri Padang
}

\begin{abstract}
The aim of this study was to analyse the implementation of regional regulations No 1 of 2019 on Retribusi Jasa Umum dalam Pengelolaan Retribusi pasar di Pasar Raya Padang. Background of this study is because several problems were found in market retribution of Pasar Raya Padang that is, a collection that does not give a ticket or evidence of payment of retribution. Limited market management capabilities to provide a place, there are still traders who do not pay retribution. As well as a lack of oversight from Padang city trade service. Formulation of the problem in this study is how the implementation of regional regulations No 1 of 2019 on Retribusi Jasa Umum dalam Pengelolaan Retribusi pasar di pasar Raya Padang. What are the constraints in the implementation of regional regulations.

This study was qualitative with descriptive method. Selection of informants was done with Purposive for decided key informants and next decided with SnowballSampling technique. This observation data collection techniques was interview and documentation study. For data analysis was done by data collection, data reduction, presentation of data, and conclusions. Then the validity of this data is tested by Triangulasi Sumber which is then analysed with data analysis techniques. Measurement toward the implementation of regional regulations No 1 of 2019. The researcher used measure of policy implementation according George C. Edward III, there are four policy implementation indicators such as, communication, resource, disposition, and bureaucratic structure.

This study reveal that implementation of the collection of market retribution was carried out by Dinas Perdagangan Kota Padang to traders who sell in Pasar Raya Padang. Based on findings and discussion The Implementation of Regional Regulations No 1 of 2019 on Retribusi Jasa Umum dalam Pengelolaan Retribusi Pasar di Pasar Raya Padang was influenced by communication, resource and attitudes of the bureaucracy and implementers. Constraints faced in the implementation of the management of market retribution in Pasar Raya Padang is less awareness of traders in paying market retribution, so that many causes arrears on market retribution and the target was not achieved.
\end{abstract}

Keywords: Policy Implementation, Market Retribution, Regional Regulations

\begin{abstract}
Abstrak
Penelitian ini bertujuan untuk menganalisis Implementasi Peraturan Daerah Nomor 1 Tahun 2019 Tentang Retribusi Jasa Umum dalam Pengelolaan Retribusi Pasar di Pasar Raya Padang. Latar belakang penelitian ini karena ditemukan beberapa permasalahan dalam Retribusi Pasar di Pasar Raya Padang yakni, Pemungutan yang tidak memberikan karcis atau tanda bukti pembayaran retribusi, Keterbatasan kemampuan pengelolaan pasar dalam menyediakan tempat, Masih adanya pedagang yang tidak membayar retribusi. Serta kurangnya pengawasan dari Dinas Perdagangan Kota Padang. Rumusan masalah pada penelitian ini adalah bagaimana Implementasi Peraturan Daerah Nomor 1 Tahun 2019 Tentang Retribusi Jasa Umum dalam Pengelolaan Retribusi Pasar di Pasar Raya Padang. Apa saja kendala dalam Implementasi Peraturan Daerah Nomor 1 Tahun 2019 Tentang Retribusi Jasa Umum dalam Pengelolaan Retribusi Pasar di Pasar Raya Padang.
\end{abstract}


Penelitian ini merupakan penelitian kualitatif dengan metode deskriptif. Pemilihan informan dilakukan dengan cara Purposive untuk menentukan informan kunci dan informan selanjutnya ditentukan dengan teknik Snowball Sampling. Teknik pengumpulan data observasi, wawancara dan studi dokumentasi. Untuk analisa data dilakukan dengan cara pengumpulan data, reduksi data, penyajian data, dan penarikan kesimpulan. Kemudian data ini diuji keabsahannya dengan Triangulasi Sumber yang kemudian di analisis dengan teknik analisis data. Pengukuran terhadap Implementasi Peraturan Daerah Nomor 1 Tahun 2019 Tentang Retribusi Jasa Umum dalam Pengelolaan Retribusi Pasar di Pasar Raya Padang. peneliti menggunakan pengukuran Implementasi Kebijakan menurut George C. Edward III, ada empat indikator Implementasi Kebijakan yaitu komunikasi, sumber daya, disposisi, struktur birokrasi.

Penelitian ini mengungkapkan bahwa pelaksanaan pemungutan retribusi pasar yang dilakukan oleh Dinas Perdagangan Kota Padang kepada pedagang yang berjualan di Pasar Raya Padang. Berdasarkan temuan dan pembahasan Implementasi Peraturan Daerah Nomor 1 Tahun 2019 Tentang Retribusi Jasa Umum dalam Pengelolaan Retribusi Pasar di Pasar Raya Padang dipengaruhi oleh komunikasi, sumber daya serta sikap dari birokrasi dan pelaksana. Kendala yang dihadapi dalam Implementasi Pengelolaan Retribusi Pasar di Pasar Raya Padang adalah kurangnya kesadaran pedagang dalam membayar retribusi pasar, Sehingga banyak menimbulkan tunggakan pada retribusi pasar dan tidak tercapainya target pertahun.

Kata kunci: Implementasi Kebijakan, Retribusi Pasar, Peraturan Daerah.

${ }^{*}$ Penulis Korespondensi

E-mail : fresha.a@yahoo.com

\section{PENDAHULUAN}

Pemungutan yaitu pembayaran oleh warga kepada negara atas layanan tertentu yang diberikan negara kepada warganya secara individu. Sedangkan menurut pasal 1 Undang-Undang Nomor 28 Tahun 2009 tentang Pajak Daerah dan Retribusi Daerah, Retribusi Daerah dimaknai sebagai pembayaran atas jasa atau pemberian izin tertentu yang secara khusus diberikan atau diberikan oleh pemerintah daerah untuk kepentingan pribadi atau perseorangan.

$$
\text { Dalam penyelenggaraan }
$$

Pemerintahan Daerah, untuk mengatur atau mengolah pasar di Pasar Raya Padang. Pemerntah Kota Padang mengluarkan Peraturan Daerah Kota Padang Nomor 1 Tahun 2019 Retribusi Jasa Umum, yg merupakan perubahan atas Peraturan Daerah Kota Padang Nomor 1 Tahun 2016 tentang Retribui Jasa Umum.
Maka dari itu, pemrintah daerah harus benar-benar memanfaatkan retalisasi berbasis pasar. Upaya pemerintah daerah untuk mengenakan pajak pasar ditujukan untuk memberikan layanan kepada penduduk atas apa yg mereka bayarkan.keberadaan layanan ini dianggap sebagai masalah yg sangat penting yg harus dijalankan dalam kerangka sistem demokrasi itu sendiri.

Berdasarkan dengan Peraturan Daerah Kota Padang Nomor 1 tahun 2019 Retribusi Jasa Umum, pada pasal 1 Nomor 34 "Retribusi Jasa Pasar adalah retribusi daerah sebagai pembayaran atas jasa pasar yang diberikan oleh Pemerintah Daerah". Biaya pasar dibebankan pada pedagang yang menggunakan layanan pasar. Fasilitas pasar yang dikenakan pemungutan diPasar Raya Padang yaitu untuk pemakaian Kios, Ios, Ruang Lepas, Meja Batu, dan Pelataran. Retribusi Pasar di Pasar Raya Padang dipungut menggunakan Surat 
Ketetapan Retribusi Daerah oleh petugas Dinas Perdagangan Kota Padang. Surat Ketetapan Retribusi Daerah yang dipergnakan dlm pemungtan retrbusi pasar tersbut yaitu berupa kartu atau karcis pungutan retribusi pada pedagang yang berjualan diPasar Raya Padang.

Tabel 1. Struktur dan Ukuran Tarif Untuk Retribusi Pelayanan Pasar
\begin{tabular}{|l|l|c|}
\hline No. & \multicolumn{1}{|c|}{ Wilayah } & Satuan \\
\hline 1) & Blok 1 s/d IV & $\mathrm{Rp} 1.500 / \mathrm{m} 2 / \mathrm{hari}$ \\
\hline 2) & Meja Batu Pasar Pembantu \& PKL & $\mathrm{Rp} 1.500 / \mathrm{m} 2 / \mathrm{hari}$ \\
\hline
\end{tabular}

Sumber : Perda Kota Padang No 1 Tahun 2019

Berdasarkan Perda Kota Padang No 1 Thn 2019 Tntang Retribusi Jasa Umum, Dalam Pasal 1 Nomor 38, "Kios merupakan bangunan semi permanen, sebagian terbuat dari kayu dan beton, dengan luas maksimum $30 \mathrm{~m} 2$. Dalam Pasal 1 Nomor 39, "Ruang lepas adalah ruangan yang terletak didalam bangunan pasar dengan luas $100 \mathrm{~m} 2$. Dalam Pasal 1 ayat 40, "Meja Batu berarti bangunan semi permanen dengan atap tanpa dinding, yang membatasi satu area ke are lainnya dengan penyediaan atau konstruksi meja batu permanen. Pada Pasal 1 ayat 41,"Pelataran adalah tempat tertentu di pasar yang diperuntukkan bagi pedagang kaki lima yang tidak permanen".

Setiap pedagang yang berdagang di pasar dikenakan pemungutan pasar. Pemungutan yaitu transfer kekayaan dari sektor swasta ke sektor publik sesuai dengan undang-undang untuk membiayai pembangunan sehari-hari dan pengeluaran pemerintah. Pengumpulan retribusi pasar dilakukan oleh pemerintah daerah melalui Dinas Perdagangan Kota Padang. Pemungutan retribusi pasar dikategorikan menjadi 2 yaitu pembayaran retribusi pasar harian dan pembayaran retribusi bulanan. Namun pada kenyataannya pemungutan retribusi pasar dirasa kurang maksimal karena kurangnya kesadaran pedagang tentang membayar retribusi pasar. Sehingga banyak menimbulkan tunggakan pada retribusi pasar.

Pungutan biaya untuk layanan pasar merupakan inti dari pengelolaan biaya untuk layanan pasar. Hal ini karena pada saat pemungutan retribusi jasa pasar terdapat proses bagaimana hasil pungutan pasar tersebut dipungut oleh pemungutan iuran jasa pasar. Agar hasil retribusi menjadi salah satu sumber pendapatan kas daerah yg digunakan untuk membiayai pembangunan dan pembiayaan lain didaerah.

Oleh karena itu Pemerintah Kota Padang mampu merancang atau mengembangkan kebijakan pengelolaan pungutan daerah yang dianggap efektif dalam meningkatkan pendapatan asli daerah.

\section{METODE PENELITIAN}

Penelitian ini merupakan penelitian kualitatif dengan metode deskriptif. Pemilihan informan dilakukan dengan cara Purposive untuk menentukan informan kunci dan informan selanjutnya ditentukan dengan teknik Snowball Sampling. Teknik pengumpulan data observasi, wawancara dan studi dokumentasi. Untuk analisa data dilakukan dengan cara pengumpulan data, reduksi data, penyajian data, dan penarikan kesimpulan. Kemudian data ini diuji keabsahannya dengan Triangulasi 
Sumber yang kemudian di analisis dengan teknik analisis data.

\section{HASIL DAN DISKUSI/ANALISIS Otonomi Daerah}

Otonomi adalah pengalihan urusan pemerintah pusat kepada pemerintah daerah yang dijalankan dalam sistem birokrasi negara. Tujuan otonomi yaitu untuk mencapai efisiensi \& efektifitas dalam memberikan layanan untuk masyarakat.

Menurut Said (dalam Christia Adisya Mega \& Ispriyarso Budi,2014) Ada empat sudut pandang yang mendasari aspek positif dan empat sudut pandang yang mendasari aspek negatif otonomi daerah.

Empat sudut pandang yang mendasari aspek positif otonomi daerah. yaitu:

1. Demokratisasi.

2. Membantu meningkatkan kualitas dan efesiensi pemerintahan.

3. Meningkatkan stabilitas dan persatuan nasional.

4. Mempromosikan pembangunan daerah.

Aspek negatif otonomi daerah didasarkan pada empat sudut pandang, yaitu:

1. Penciptaan fragmentasi yang tidak terduga dan pemisahan bagian-bagian.

2. Melemahnya kualitas pemerintah.

3. Penciptaan celah besar antar wilayah.

\section{Peranan Pasar dalam Keuangan Daerah}

Pasar merupakan salah satu tempat dimana masyarakat dapat berbisnis. Dengan adanya pasar maka akan terjadi siklus peredaran uang untuk meningkatkan perekonomian masyarakat padang. Pertumbuhan ekonomi ini secara tidak langsung mempengaruhi perkembangan penerimaan retribusi pasar. Pasar juga merupakan unit bisnis yang berperan strategis dalam berfungsinya sinyal distribusi dari produsen hingga konsumen yang memperlukan suatu produk. Dengan demikian, boleh dikatakan bahwa pasar merupakan pemasok langsung kebutuhan sehari-hari masyarakat dan berbagai interaksi di dalamnya dengan partisipasi unsur pemerintah, swasta dan masyarakat. kondisi ini menegaskan bahwa pasar memberikan kontribusi yang signifikan bagi pelaksanaan pembangunan di daerah, karena pungutan retribusi dapat meningkatkan pendapatan asli daerah. biaya pasar dibebankan setiap hari. Jadi pendapatan keuangan daerah dari pembalasan pasar juga setiap hari.

\section{Konsep Pajak dan Retribusi}

a. Pajak

Pada umumnya, pajak adalah sumbangan masyarakat ke kas negara secara hukum, sehingga dapat dikumpulkan tanpa menerima kompensasi langsung. Pajak dipungut oleh pihak berwenang sesuai dengan hukum untuk menutupi biaya produksi barang dan jasa kolektif untuk mencapai kesejahteraan umum.

Menurut Adrian Sutedi (2011:1), pajak dipahami dari sudut pandang ekonomi sebagai pengalihan sumber daya dari sektor swasta ke sektor publik. Pajak mengubah dua situasi. Pertama, penurunan kemampuan masyarakat untuk mengelola sumber daya guna mengendalikan barang dan jasa. Kedua, meningkatkan kemampuan keuangan negara untuk menyediakan barang dan jasa publik yang menjadi kebutuhan publik.

Sedangkan pengertian perpajakan dari segi hukum menurut 
Soemitro dan Sutedi (2011:1) merupakan kewajiban yang mewajibkan warga negara untuk menyumbang sejumlah pendapatan tertentu kepada negara, negara berhak menegakkan, dan pajak harus digunakan untuk negara.

Dalam Bohari (2012:133-135), ada dua fungsi pemungutan pajak :

1) Fungsi Budgetair, yaitu menginvestasikan uang ke kas negara.

2) Fungsi Regulerendatau fungsi regulasi, yaitu pajak merupakan instrumen pemerintah untuk mencapai tujuan tertentu dibidang ekonomi, moneter, sosial, budaya, dan politik.

A. Retribusi

Retrbusi merupakan biaya yang dikenakan oleh pemerintah daerah sebagai pembalasan atas penggunaan layanan tertentu yang disediakan oleh pemerintah. Dengan demikian, dalam hal ini terdapat remunerasi langsung yang dapat digunakan oleh pembayar retribusi.

Pendapat Siahaan (2008:5), pemungutan merupakan pembayaran wajib oleh warga untuk negara dikarenakanadanya pelayanan tertentu yang diberikan oleh negara kepada warga secara individu. jasa tersebut bisa mengatakan bahwa layanan ini langsung, yaitu hanya mereka yang membayar retribusi yang diberi imbalan layanan dari negara. Salah satu contoh retribusi adalah biaya layanan pasar yang diatur oleh pemerintah. Siapapun yang ingin memanfaatkan peluang pasar harus membayar biaya layanan pasar yang ditetapkan pemerintah.

Sesuai dengan hukum indonesia yang berlaku, pemerintah daerah hanya dapat mengenakan biaya kepada pengguna. Jadi, pungutan daerah. beberapa karakteristik yang melekat pada retribusi daerah yang saat ini dikenakan di indonesia adalah sebagai berikut:

1. Pemungutan adalah biaya yang dipungut berdasarkan hukum dan peraturan setempat yang berlaku.

2. Pendapatan retribusi masuk ke kas daerah.

3. Pihak yang membayar retribusi menerima prestasi timbal balik langsung dari pemerintah daerah atas pembayaran yang dibayarkan.

4. Retribusi dibayarkan jika ada jasa yang dilakukan oleh org atau badan hukum.

5. Sanksi retribusi merupakan sanksi ekonomi adalah apabila tidak membayar retribusi tidak akan mendapatkan pelayanan yg diberikan oleh pemerintah.

\section{Pendapatan Asli Daerah (PAD)}

Pendapatan Asli daerah yaitu pendapatan asli daerah yang masuk ke kas daerah yang bersumber dari kinerja daerah itu sendiri, pendapatan asli daerah merupakan pendapat dari pengelolaan kekayaan daerah tertentu PAD lain yang sah berdasarkan peraturan daerah sesuai dengan ketentuan yang berlaku. Hukun dan regulasi.

\section{Kebijakan Publik}

Chief J. O. Udoji dalam Wahab (2014:15), mendefinisikan kebijakan publik sebagai "an santioned course of action addressed to a particular problem or group of related problems that affect society at large" (Tindakan yang berwenang yang mengarah ke tujuan spesifik yang saling terkait yang mempengaruhi mayoritas anggota komunitas).

Lemieux (1995:7) dalam Wahab (2014:15), merumuskan kebijakan publik sebagai berikut:

"The product of activities aimed at the resolution of public problems in the 
environment by political actors whose relationship are structured. The entire process evolves over time" (Produk kegiatan yang bertujuan untuk menyelesaikan masalah sosial yang timbul pada kondisi tertentu, dan dilakukan oleh aktor politik yg terstruktur. Seluruh proses kegiatan ini berlangsung terus menerus).

\section{Implementasi Kebijakan Publik}

Vanmeter dan Vanhorn dalam

Agustino

(2006:153)

mengungkapkan

definisi

implementasi kebijakan sebagi berikut; "Tindakan tindakan yang dilakukan baik oleh individu individu atau pejabat- pejabat atau kelompokkelompok pemerintah atau swasta yang diarahkan pada tercapainya tujuan tujuan yang telah digariskan dalam keputusan kebijaksanaan".

Definisi

implementasi

kebijakan yang lain dikemukakan oleh Daniel Mazmanian dan Paul Sabatier dalam Agustino (2006:153) mengungkapkanbahwa implementasi kebijakan adalah; "Pelaksanaan keputusan kebijakan dasar, biasanya dalam bentuk undang undang, namun dapat pula berbentuk perintah perintah atau keputusan keputusan eksekutif yang penting atau keputusan badan peradilan. Lazimnya, keputusan tersebut mengidentifikasikan masalah yang ingin diatasi, menyebutkan secara tegas tujuan atau sasaran yang ingin dicapai, dan berbagai cara untuk menstrukturkan atau mengatur proses implementasinya".

\section{Pengelolaan Retribusi Pasar}

Pengelolaan

yaitu

pengendalian dan penggunaan semua sumber daya yang digunakan sesuai dengan rencana untuk menyesuaikan tujuan kerja tertentu. Secara umum, pengelolaan adalah mengatur dan menggerakkan sekelompok orang dengan segala kemampuan untuk mencapai sasaran tertentu yang telah ditetapkan sebelumnya. Sasaran yang dimaksudkan juga dapat berbedabeda tergantung pada ruang untuk kolaborasi yang tertarik dapat mencapai tujuan yang dilakukan oleh individu yang melakukan upaya terbaik mereka melalui tindakan yang telah diidentifikasikan sebelumnya.

Ada beberapa indikator yang penulis gunakan untuk mengukur Implementasi Peraturan Daerah Nomor 1 Tahun 2019 Tentang Retribusi Jasa Umum dalam Pengelolaan Retribusi Pasar di Pasar Raya Padang yakni indikator pengukuran menurut George C. Edward III, ada empat indikator yaitu komunikasi, sumber daya, disposisi, struktur birokrasi.

\section{a. Komunikasi}

Komunikasi merupakan salah satu faktor penunjang keberhasilan pencapaian tujuan dan ide-ide yang digunakan aparatur pemerintah sehingga dapat diterima dengan jelas oleh masyarakat. Suatu kebijakan harus dikomunikasikan dengan cara yang tepat, akurat, dan konsisten. Komunikasi sangat penting untuk memastikan bahwa pembuat kebijakan dan pelaksana kebijakan pungutan pasar lebih konsisten dalam menerapkan kebijakan yang akan diterapkan pada pungutan wajib.

Ada beberapa indikator yang digunakan untuk mengukur keberhasilan variable komunikasi, yaitu:

a. Kejelasan Informasi

Komunikasi yang diterima oleh pembuat kebijakan harus jelas. Dengan kejelasan infomasi, dia akan mendukung pihak manapun dan mempengaruhi hasil kebijakan. Informasi yang dikomunikasikan secara lisan tentang kebijakan pengelolaan biaya pasar dapat 
menimbul pertanyaan yang jelas atau tidak.

Berdasarkan temuan dilapangan, maka penulis dapat menyimpulkan bahwa informasi yang diterima dari pembuat kebijakan (Dinas Perdagangan Kota Padang) dan yang menerima kebijakan tersebut (Pedagang Kaki Lima di Pasar Raya Padang) sudah sangat jelas, karena selain melalui para petugas pemungutan retribusi pasar, pelaksanaan pengelolaan retribusi pasar kepada pedagang kaki lima ini juga diatur dalam Peraturan Daerah Nomor 1 Tahun 2019 Tentang Retribusi Jasa Umum.

b. Konsisten Informasi yang disampaikan

Informasi yang disepakati adalah kebutuhan untuk memberikan informasi agar tidak terjadi kesalahan pada berbagai aspek, dalam hal ini informasi tersebut ditransmisikan secara lisan maupun dalam bentuk draft yang dalam pelaksanaanya tetap konsisten atau tidak berubah. Karena selain kejelasan informasi juga harus dibarengi dengan pelaksanaan yang konsisten agar sesuai dengan sebenarnya serta target retribusi pasar dapat terealisasikan sehingga Pendapan Asli Daerah dapat meningkat.

Berdasarkan temuan dilapangan, maka penulis dapat menyimpulkan bahwa informasi yang disampaikan oleh petugas pelaksana pemungutan retribusi kepada para pedagang pasar sudah konsisten, karena para petugas melandasi pelaksanaan tugas berdasarkan perda yang telah ditetapkan.

\section{b. Sumber Daya}

Dalam suatu kebijakan, informasi yang disampaikan jelas dan konsisten, namun tidak hanyan faktor-faktor tersebut yang mempengaruhi pelaksanaan kebijakan. Dalam hal ini tentang kecukupan jumlah pegawai, informasi, kewenangan, serta sarana dan prasarana yang mendukung pelaksanaan tata kelola pasar diPasar Raya Padang. Indikator sumber daya terdiri dari yaitu:

1. Jumlah Pegawai

Salah satu kegagalan yang sering terjadi adalah karena staf/pegawai yang tidak memadai dan tidak kompeten di bidangnya masing-masing.berkenaan dengan pemungutan retrbusi pasar dibutuhkan pegawai yang memiliki kemampuan yang memadai untuk melaksanakan tugasnya.

2. Informasi yang diperlukan. Informasi merupakan sumber penting dalam implementasi kebijakan, dan memiliki informasi yang memadai berkontribusi besar terhadap implementasi kebijakan. Informasi dalam hal ini adalah informasi tentang bagaimana melaksanakan atau menjalankan sebuah kebijakan pengelolaan pungutan pasar, yang secara sangat jelas tertuang dalam Peraturan Daerah Nomor 1 Tahun 2019 tentang Retribusi Jasa Umum. Informasi yang diterima pelaksana mengenai pelaksanaa program yang tepat, mulai dari fasilitas dan subjek, tingkat pengumpulan, dan diakhiri dengan pelaksanaan dan kepatuhan staf dalam melaksanakan tugasnya masing-masing.

Berdasarkan temuan dilapangan, maka penulis dapat menyimpulkan bahwa informasi mengenai pelaksanaan kebijakan pengelolaan retribusi pasar ini sangat jelas, dan personel yang terlibat didalam nya harus menjalankan tugasnya sesuai dengan aturan yang ditetapkan.

3. Kewenangan.

Secara umum, wewenang harus formal untuk melaksanakan 
kebijakan. Wewenang adalah kewenangan atau legalitas bagi pelaksana untuk melaksanakan kebijakan tertentu. Ketika kekuasaan tidak ada, maka kekuasaan pelaksana tidak dilegitimasi dimata masyarakat, yang dapat mengganggu pelaksanaan kebijakan. Amanat para pengambil kebijakan pengelolaan pungutan pasar adalah untuk meningkatkan pendapatan retribusi pasar, agar pendapatan daerah juga meningkat.

4. Sarana yang diperlukan

$$
\text { Untuk melaksanakan }
$$

kebijakan pengelolaan retribusi pasar diPasar Raya Padang diperlukan sarana dan prasarana seperti perkantoran dan perlengkapan lainnya untuk mendukung pelaksanaan tugasnya dengan baik.

Berdasarkan temuan dilapangan, Dengan demikian, penulis dapat menyimpulkan bahwa dana infrastruktur yg disediakan oleh negara untuk melaksanakan kebijakan pemungutan retribusi pasar di Pasar Raya Padang sangat berpengaruh terhadap pelaksanaan proses pemungutan retribusi pasar yg dilakukan oleh petugas pelayanan yg memadai juga dapat berjalan dengan baik. Kerja pelayanan yg diberikan pemerintah kepada pegawai resmi adalah: Kantor UPTD Pasar Raya Padang yg terletak di Blok IV, Komputer didalam ruangan.

\section{c. Disposisi (Sikap Birokrasi dan Pelaksana)}

Disposisi

adalah

kecenderungan dari satu faktor yang mempengaruhi karakteristik suatu aparatur pemerintah dalam menjalankan tugas sesuai dengan peraturan yang diperintahkan dalam mempengaruhi tingkat keberhasilan dalam pencapaian tujuan dari suatu kebijakan.

a. Komitmen Aparatur Pelaksana
Komitmen instansi pelaksana terhadap kebijakan dapat mendukung implementasi kebijakan sesuai dengan keinginan. Kebijakan tidak dapat bekerja dengan baik dan mencapai hasil yang diinginkan jika badan pelaksana tidak melaksanakan tugas dan tanggung jawabnya sebagai pelaksana kebijakan. Dalam hal ini penulis memfokuskan pada kewajiban petugas pemungutan retribusi pasar diPasar Raya Padang.

Berdasarkan temuan dilapangan, maka penulis dapat menyimpulkan bahwa aparatur pemungut retribusi pasar wajib menjalankan tugasnya sesuai dengan tanggung jawab dan kewenangannya, serta ketentuan yang tertuang dalam Peraturan Daerah Nomor 1 Tahun 2019 Tentang Retribusi Jasa Umum.

b. Kejujuran Aparatur Pelaksana

Kejujuran merupakan sikap yg mutlak diperlukan seseorang petugas, karena tanpa kejujuran dalam melakukan pemungutan retribusi, kepercayaan masyarakat akan hilang kepada petugas sebagai pemungut biaya. Kejujuran harus dibangun pada saat awal implementasi diluncurkan, sebelum hasil yang sebelumnya ditargetkan tercapai.

Sikap kejujuran aparatur yang melaksanakan pemungutan retribusi pasar kepada pedagang kaki lima di Pasar Raya Padang. Para pegawai tersebut wajib memiliki sikap kejujuran yang tinggi untuk dapat memungut retibusi pasar, terutama terkait pelaporan simpanan dari retribusi pasar yang semuanya harus masuk ke kas daerah.

Berdasarkan temuan dilapangan, maka penulis dapat menyimpulkan bahwa setelah para petugas melakukan pemungutan retribusi pasar kepada pedagang kaki lima, hasilnya langsung disetorkan ke bendahara untuk dilakukan 
perhitungan dan akan dipertanggungjawabkan.

c. Karakter Demokratis dari Aparatur Pelaksana

Hakikat demokrasi yang ada dalam pikiran penulis adalah sifat aparatur pelaksana yang memungkinkan semua kebijakan yang ada diadopsi dan dijalankan sesuai dengan tanggung jawabnya, serta untuk memperoleh hasil yang telah dicapai.

Berdasarkan temuan dilapangan, maka penulis dapat disimpulkan bahwa setiap eksekutif benar-benar demokratis dalam menjalankan tugasnya dan dapat dengan sabar menerima hasil pemungutan retribusi meskipun tidak berhasil, pejabat juga harus mengingatkan mereka bahwa adalah mandat mereka untuk meningkatkan pendapatan reward pasar.

d. Struktur Birokrasi

Menurut George C. Edward III dalam Mulyadi (2015:68) mengatakan bahwa Struktur Birokrasi merupakan variabel keempat dalam implementasi kebijakan, struktur birokrasi menjadi hal yang penting dalam sebuah kebijakan yang mencakup mekanisme dan Struktur organisasi pelaksanaan. Struktur organisasi yang bertugas dalam implementasi kebijakan mempunyai pengaruh signifikan terhadap pelaksanaan kebijakan. Salah satu aspek yang dapat dijadikan pedoman bagi implementor dalam sebuah pelaksanaan kebijakan.

Berdasarkan temuan dilapangan, maka penulis dapat menyimpulkan hal tersebut saat melaksanakan pengelolaan retrbusi pasar sudah dilakukan sesuai dengan Standar Operational Prosedur (SOP). Dalam pelaksanaan pengelolaan retribusi pasar sudah mempunyai SOP, dalam setiap melakukan kegiatan sesuai dengan SOP yang telah ditetapkan, menerima SOP terlebih dahulu baru melaksanakan kegiatan tersebut.

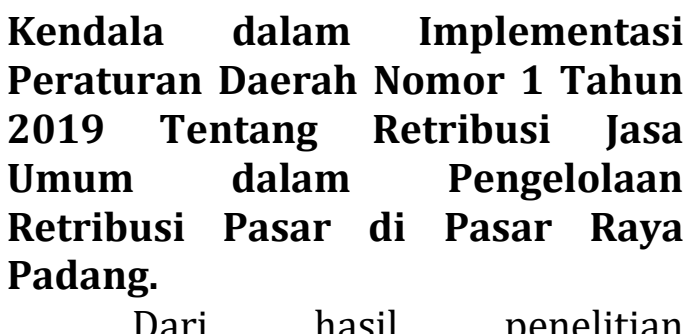
ditemukan beberapa kendala yaitu kendala yang timbul dari lingkungan internal (dalam) maupun kendala berasal dari lingkungan eksternal (luar).

\section{Kendala Internal}

Kendala internal yaitu Kurangnya SDM, peraturannya belum memadai, sanksinya terlalu ringan, dan rekrutmen tenaga perlu diupgrade pada Perusahaan Daerah (PD) Pasar Raya.

\section{Kendala Eksternal}

Kendala eksternal adalah kurangnya kesadran masyarakat pedgang dlm membayar retrbusi pasar yg mengakibatkan banyak terjadi penunggakan retrbusi sehingga sulitnya pihak dinas dalam mengelola keuangan. Dengan banyaknya ditemukan tunggakan pembayaran retrbusi pasar oleh pedagang.

\section{KESIMPULAN}

Dari penelitian yg sudah dilaksanakan sebelumnya, penulis telah mendapatkan hasil dan pembahasan mengenai hasil peneltian tersebut, maka dapat dismpulkan bahwa:

1. Dalam Implementasi Peraturan Daerah Nomor 1 Tahun 2019 Tentang Retribusi Jasa Umum dalam Pengelolaan Retribusi 
Pasar di Pasar Raya Padang. Dalam pelaksanaannya, Dinas Perdagangan Kota Padang belum mampu memberikan pelayanan yang maksimal. Adapun indikator untuk mengukur keberhasilan tersebut adalah komuikasi, sumber daya, disposisi, struktur birokrasi. Dari empat indikator tersebut, satu indikator seperti sumber daya, Jika dilihat dari kendala internal yaitu hal ini ditandai dengan kurangnya sumber daya. Sedangkan dilihat dari kendala eksternal yaitu kurngnya kesdaran para masyarakat pedgang untk membyar retrbusi pasar, sehingga mengakibatkan banyak menimbulkan tunggakan pada retribusi pasar, dan tidak tercapainya target pertahun.

2. Kendala yang dihadapi dalam Implementasi Peraturan Daerah Nomor 1 Tahun 2019 Tentang Retribusi Jasa Umum dalam Pengelolaan Retribusi Pasar di Pasar Raya Padang meliputi kendala internal dan eksternal. Kendala internal yaitu kurangnya SDM, serta peraturannya belum memadai, sanksinya terlalu ringan, dan rekrutmen tenaga perlu diupgrade yg namanya PD Pasar Jaya. Sedangkan kendala eksternal yaitu kurangnya kesdaran para pedgang pasar diPasar Raya Padang utk membyar retrbusi pasar. Selain itu akibat kurangnya kesadaran tersebut sehingga mengakibatkan banyaknya tumpukan terhadap retribusi pasar.

Dari semua hasil penelitian yg dilakukan oleh penulis, maka penulis akan memberikan beberapa saran, antara lain:
1. Diharapkan kepada Dinas Perdagangan Kota Padang untuk meningkatkan kinerjanya dalam mengembangkan pelaksanaan kebijakan retribusi pelayanan pasar kearah yang lebih baik agar pendapatan daerah pun menjadi lebih optimal.

2. Bagi masyarakat pedagang harus meningkatkan kesadaran diri untuk membayar retribusi pada tepat waktunya, agar tidak terjadinya penunggakan, dan dapat berjalan dengan baik sehingga target untuk pendapatan retribusi dan pendapatan daerah dapat sesuai dengan target yg diinginkan.

\section{REFERENSI}

Agustino, Leo. 2006. Politik \& Kebijakan Publik. Bandung. AIPI Bandung.

Bohari.2012. Pengantar Hukum Pajak. Jakarta: RajaGrafindo Persada.

Sutedi, Adrian. (2011). Hukum Pajak. Jakarta: Sinar Grafika.

Siahaan, Marihot P. 2008. Pajak Daerah dan Retribusi Daerah. Jakarta: PT. Raja Grafindo Persada.

Wachab, Solichin Abdul.2004. Analisis Kebijakan; Dari Formulasi ke Penyusunan Model Model Implementasi Kebijakan Publik. Jakarta. PT.Bumi Aksara.

Christia, A. M., \& Ispriyarso, B. (2019). "Desentralisasi Fiskal Dan Otonomi Daerah Di Indonesia". Law Reform, Vol.15No.1, 149-163. 


\section{Undang-Undang}

Undang-Undang No.28 Tahun 2009

tentang Pajak Daerah dan Retribusi

Daerah.

Peraturan Daerah Kota Padang No.1

Tahun 2019 tentang Retribusi Jasa

Umum. 